\section{Agricultural M anager's Dilemma at St. Croix Valley Foods, Inc.: A Decision Case in Processing Crops Agriculture}

\author{
David W. Davis
}

$\mathbf{T}$ he vegetable processing industry had become well established in the upper Midwest by the 1950s, using some 500,000 acres and emphasizing the large-seeded crops such as peas, snap beans, lima beans, and sweet corn. Harvested at a point of rapid change in the plant growth and development process, a field of any of these crops could provide an excellent product on one day and 2 or 3 days later an over-age product that might demand a much lower price, if it could be sold at all.

Not surprisingly, skilled management and careful attention to organization of the growing and processing operation were mandatory in a successful company. The industry consisted of a number of processing firms and their independent contract growers. Some of the firms were national or international in the scope of their production and packing operations and had many factory locations. Others were regional or local, consisting of one to several factory sites. At each site responsibility tended to be structured along two lines; i.e., factory operations and agricultural operations. The re sponsibility for liaison between the factory and the harvest of raw product from field sites resided with the agricultural manager. Company success during the packing season was contingent on the continuous flow of highquality raw product from the field to the factory.

\footnotetext{
${ }^{I}$ Professor.

Department of $\mathrm{H}$ orticultural Science, U niversity of M innesota, St. Paul, M N 55108

Published as paper no. 19,528. Journal Series, $A \& \&$ turd Experiment Station, Univ. of M innesota, St. Paul.
}

In Aug. 1989 John Blume, agricultural manager, St. Croix Valley Foods, Inc., found himself in a difficult situation-more sweet corn fields were nearing optimum maturity than could be processed. A decision had to be made on the harvest sequence for these fields and on whether or not some would be abandoned and, if so, which ones. Preharvest sampling data and planting date were important factors in determining harvest timing, but many other factors would enter into the decision when several fields appeared to be maturing at the same time.

\section{St. Croix Valley Foods, Inc.}

St. Croix Valley Foods, Inc., with headquarters at Preston, Minn., was fairly typical of most midwestern vegetable processing firms in its structure, historical development, and operating protocols. Considerable expansion and modernization had taken place in re cent years, and several plant locations in the upper Midwest were owned in 1989. The companywas not limited to sweet corn and green peas, but these two vegetables were canned at all locations. The total area of sweet corn and green peas under contract to the company averaged more than 15,000 acres annually.

The plants were favorably located in several respects. First, they were sufficiently close to one another to permit some economy in both field and factory management. Second, they were located within hauling distance from irrigated lands. Third, the plants were sufficiently close to one another to permit some exchange (internal sale) of raw product and sufficiently close to other vegetable-processing companies to permit an occasional external sale or purchase of raw product as supply and demand dictated. Occasionally, sweet corn had been hauled up to 200 miles for processing. Finally, the plants were located close to good-quality farmland operated by skilled farmers and to a labor pool for summer help.

A bout $20 \%$ of the company's sweet corn was grown under irrigation, providing some opportunity to reduce the risk of drought effects on dryland production. Furthermore, the sandy, irrigatable soils provided an earlier planting date and permitted planting and harvesting sooner following rains. Thus, the higher cost per acre of production under irrigation was offset by reduced overall risk and, frequently, by the higher yields and more uniform raw product quality from the irrigated land.

The summer vegetable pack normally began with a 6-week green pea pack starting in mid- June. Following a 4 - to 8 -day down period after peas, a 7to S-week sweet corn pack began. It was in the company's best interest to begin the season as early as possible; to process an even flow of raw product on a day-to-day, two-shift basis; and to complete as much of the season as possible by Labor Day. After that day, the temporary summer help was less available due to school conflicts, and peak production at the factory was progressively more difficult to maintain.

\section{Responsibilities of the agricultural manager}

Blume had the ultimate responsibility for providing a uniform flow of high-quality raw product during the harvest season for each crop and for all agricultural phases at the various locations, including contracting, selection of production locations, designing planting and harvesting schedules, pest control, crop management and consultation for contract growers, equipment acquisition and maintenance, and harvesting and delivery of product. He shared responsibility with the factory manager and top manage ment in forming the annual plan and the sweet corn acreage contract.

Blume had been with the company for several years. Following graduation from college he had worked first for another company for nearly 10 years before joining the firm as agricultural manager. In this capacity he supervised several field representatives, each re sponsible for a number of contract growers within a "territory." These representatives provided most of the direct liaison between the company and the contract growers and were the first line of supervision above the temporary (summer) crew-chief level.

In addition to the field representatives, Blume was assisted by Mark Gravely. Gravely monitored and interpreted the pregrade data and spent much of each day scouting the maturing fields. He worked across the various territories assigned to the field representatives and was in frequent contact with Blume by radio. He had been with the company since 1985, following completion of his MS. 


\section{Crop establishment}

Each spring, sweet corn planting began as early as was commensurate with good emergence, but generally not before the last week of April. With the rapid day-to-day change in raw product maturity near harvest, uniformity of emergence following planting was important for optimizing yields. Thus, plants that would emerge 2 or 3 days earlier or later than the majority in the stand would become a detriment to yield and quality. Such plants acquired a status similar to weeds, using production resources without providing economic return. Seedbed preparation, soil uniformity, seed vigor and uniformity, and planting care could have important influences on stand and uniformity of plant development.

Planting sequence was based on the heat unit system, using a 50F base temperature. Thus, sufficient acreage was planted the first day of the planting season to keep the factory busy for 1 day at harvest. The company normally planned to operate two 10-h shifts and to pack $\approx 80$ tons of raw product per hour. Hence, the factory would need $\approx 1600$ tons per day, which translated to 270 acres, if yield were projected to be 5.9 tons/ acre, the state average. In reality, the average daily acreage that could be packed sometimes increased slightly near the end of the season ifshortage of subsoil moisture and cool, cloudy weather impeded development and, therefore, reduced yield. At planting time, heat units accumulated slowly, whereas at harvest in midsummer they accumulated rapidly. Thus, based on average heat unit accumulation per day at harvest, a similar accumulation had to occur after the first planting, before the second planting could be made. Hence, even though the fields for the next unit of 270 acres might be ready to plant, one had to wait, if temperatures were cool, until the required heat units had accumulated to ensure that the first planting had a sufficient lead before the second planting was made.

Thus, the total packing season (tonnage) could be divided into a se ries ofacreage (actually tonnage) units, with each unit defined as the daily capacity of the factory. Because of 1) the use of several different varieties, each with a different maturity; 2) local differences in temperatures; 3) "fast" and "slow" soils; and 4) rainy days that prevented planting or harvesting, the system became fairly complicated, and evenness of product flow, although generally good, sometimes was not quite as exact as one would have liked. Therefore, in the vegetable processing industry, there were some inherent risks and inefficiencies as compared to a manufacturing industry based on a nonperishable, nonweather-related product.

\section{Product maturity and grade}

In the processing industry optimum maturity of sweet corn for processing was determined by several ways as listed below. Some were subjective, while others, such as kernel moisture and probable factory recovery, could be measured or calculated. In practice, a combination of the measured and subjective methods was used.

The preharvest monitoring of a field of maturing sweet corn progressively increased as the field approached optimum maturity. Beginning at $\approx 10$ days before projected harvest, 25-ear samples were harvested every 2 days from a predetermined point in the field. If the field (or crop) was perceived to be variable, perhaps more than one sample and sample location would be used. Generally, the samples were taken between 4:00 and 9:00 AM. Although decisions as to which fields to harvest next were made throughout the day, the plan for each harvest day ideally was crystallized by 5:00 PM the preceding day, unless rain, storms, or equipment breakdown occurred after that time.

Pregrade data taken from these samples were a major factor in final determination of harvest date. The samples were taken to the factory location. The ears were husked and linedout, from apparently most mature to apparently least mature, on an inspection table. The following data were recorded.

Subjective: 1) kernel color and its variability from butt to tip; 2) kernel fill and depth from butt to tip; 3) degree of seed set; 4) insect damage and other problems; 5) number of ears judged as ready for harvest; 6) kernel appearance from a cut sample composited across the ears.

Objective: 1) kernel moisture from the cut composited sample; 2) probable factory recovery (degree of cut-corn yield from snapped, unhusked yield).
The samples from the various fields were compared with one another and also against a mental standard. The samples receiving greatest attention were from those fields that were nearest to optimum maturity. The differential appearance of each hybrid at maturity and its characteristic pattern of change with time as it approached maturity had to be recognized and understood.

Percent kernel moisture was the most important single factor on which harvest decisions were based during the final 10 days. The highest-quality cut corn from most of the standard (su) sweet corn hybrids was obtained at a kernel moisture level of $72 \%$ to $73 \%$. [For supersweet (high-sugar) hybrids, such as sh-2 and se types, the optimum moisture level was higher, approaching $78 \%$ to $79 \%$.] At $74 \%$ to $75 \%$ moisture, the flavor and taste were good, but kernel size and uniformity, color, and cut-corn yield of su hybrids were below par. At $70 \%$ to $71 \%$, a critical dividing point, yield was higher, but the cut corn appeared older (large, darker yellow kernels) and might have been tougher. The company's experience was that the pregrade sample moisture level taken one day was what you would get if you harvested the field the next day.

In the simplest sense, the industry used three grade designations to identify its sweet corn packed product for pricing and inventory purposes. These were, in declining order of quality, fancy, extra-standard, and standard. Although these were determined subjectively from company to company and without the use of regulatory standards, they were sufficiently meaningful and stable across companies and years to provide a basis for buying and selling. However, it was to be expected that there were vintage years and down years, as well as reputation differences from one company to another.

St. Croix Valley Foods recognized two additional quality grades ofpacked, cut sweet corn. First, they recognized a high-fancy grade, a notch above fancy. Second, they would, on occasion, pack a low-standard grade, if they anticipated a market outlet. In practice, the quality grade was assigned in the quality assurance laboratory after canning. Thus, other factors could and did enter into the decision.

Cut-corn kernel moisture level 
was a good predictor of quality grade. With 'Jubilee', the high-fancy and fancy grades would be in the $72 \%$ to $73 \%$ range, and the split between standard and extra-standard was $\approx 71 \%$. Standard (su) sweet corn hybrids would experience a $0.75 \%$ to $1 \%$ kernel moisture loss per day, but this could vary with temperature, perhaps rising slightly above $1 \%$ on a very warm day and virtually not changing at all as the temperature moved below the base temperature for corn (50F), when physiological development virtually stopped.

In addition to percent cut-corn moisture, the visual judgment as to how many of the 25 ears in each sample were ready for canning was a very important subjective decision that permitted the mental integration of other factors. The company believed that if more than three or four of the 25 were judged as not ready, more time should pass or could be allowed to pass before the field was harvested. Frequently, in borderline situations, a minus or plus designation would be used to further indicate the degree of harvest readiness. While the visual categorization of ears as ready or not ready would seem to the casual observer as a very imprecise evaluation, experience showed that it correlated very closely with percent moisture and with postharvest grade evaluation.

In a generic sense, the relative value of the quality grades and yield were interrelated (Exhibit 1). Because quality grade primarily reflected degree of maturity, as the quality curve declined the yield curve increased, and at the same time, the wholesale (and retail) value per case of the canned product declined. Thus, one must compromise between quality and cutcorn yield in setting the harvest date. The date that Blume set for a specific field might be influenced by several factors, such as 1) the grade distribution plan for the company and the actual distribution packed thus far in the season for each grade, 2) the location of the field relative to the location of the harvest equipment (it may be practical to harvest a day early or a day late), 3) the degree of uniformity of the field (if nonuniform you might wait longer), and 4) whether canned corn was overly abundant or in short supply in the industry as a whole. Of course, many other uncontrollable factors, such as rain, anticipated rain,

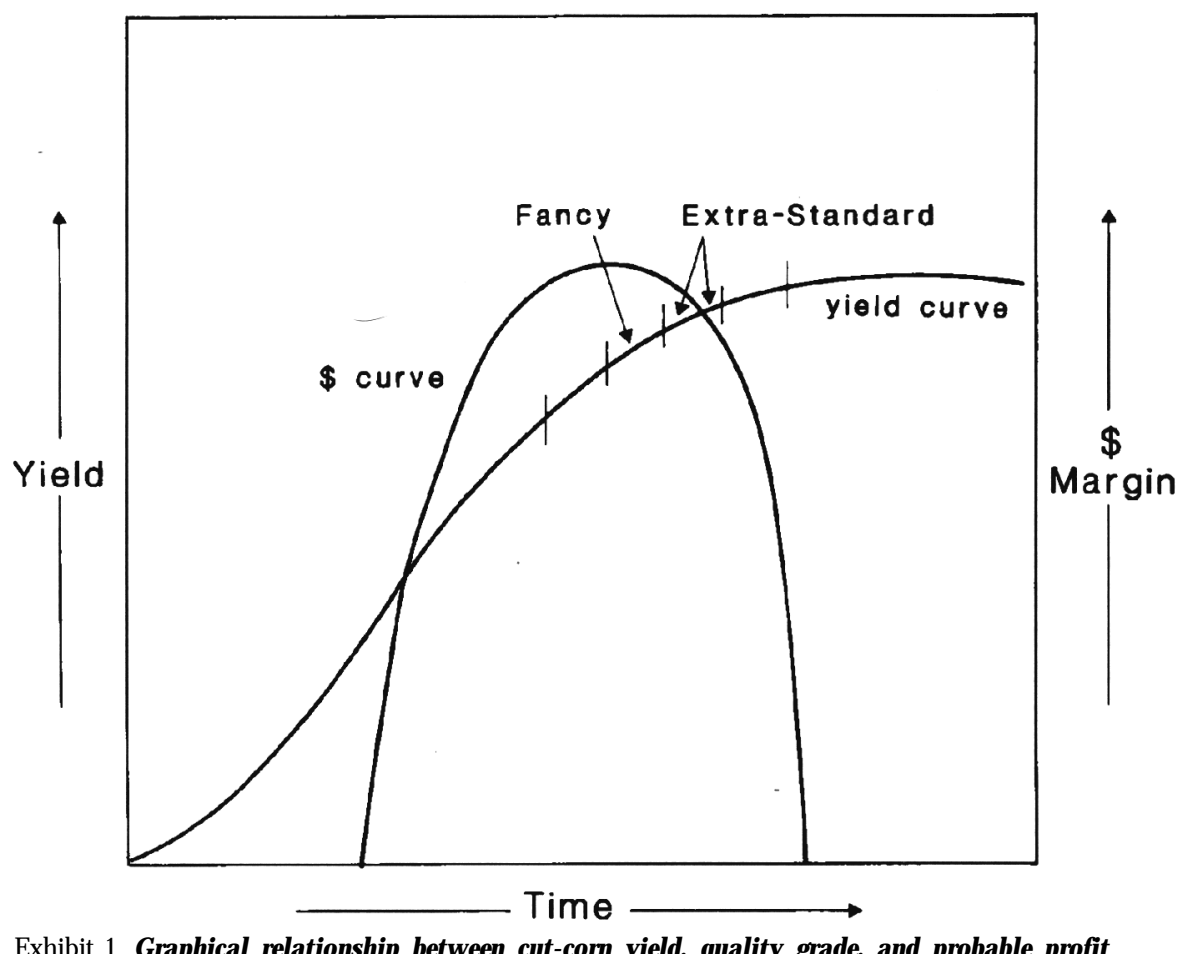

Exhibit 1. Graphical relationship between cut-corn yield, quality grade, and probable profit margin for processed sweet corn.

and equipment breakdown, also might influence harvest decisions.

\section{H arvest strategy}

The company used five harvest crews. Each consisted of a self-contained, six-row harvester and at least five trucks. The number of trucks would increase with distance of the field from the factory. Optimally, the corn from one 14-h harvesting shift would supply the factory for its two 10-h shifts. Generally, the crews worked in the same or nearby fields and, weather permitting, would complete a field before moving on.

Although contract acreage was scattered over a 60-mile radius from the factory, there generally was a clumping of fields in certain localities. While there might be other reasons for this clumping, such as suitable soil type, it also improved harvesting efficiency. Thus, it was unlikely that a single contract field of 30 or 40 acres would be isolated by 10 or 20 miles from all other contract fields, unless it was strategically located between major localities or between one of these and the factory.

Ideally, harvesting in one locality would be completed before the crews moved to a second. In practice, however, rains at planting and/ or at harvest and other factors frequently made it necessary to change harvest locality before all fields at that locality were completed. Other logistical maneuvers would effect some economy in that situation; e.g, harvesting might proceed on a kind of rotational basis among localities.

\section{The 1989 Plan}

The plan or "budget" developed in Fall 1988 was to pack 9238 acres of sweet corn from 9500 planted acres in 1989. Contracts were signed in January and February to provide this acreage. Many factors entered into the decision on acreage total, but the main ones were: 1) the existing sweet corn pack inventory for the company from the year before, as well as that assumed for the industry as a whole; 2) expected market strength for the product, based on market analysis; and 3) expected per-acre yields based on historical records for the soil types and farmer management systems with which the company generally contracted its acreage.

Projections of packed product expected from the 9500 acres also were made. Thus, based on historical yields, the acreage was projected to provide 54,406 tons of snapped (unhusked, raw) product convertible to $1,900,000$ cases of 303 equivalent. (The company used 303-mm, 8-oz, and 12-oz cans that were packed at 24, 48 , and 24 per case, respectively, but 
across the industry, the measurement unit for communication and reporting was the standard case of 303-mm cans.) These pack projections were aimed at a $20.0 \%, 71.3 \%, 8.7 \%, 0.0 \%$, and $0.0 \%$ proportion for grades $\mathrm{A}$ (high fancy), B (low fancy), C (extra-standard), D (standard), and E (low standard), re spectively (Exhibit 2).

The budgeted daily production of the processing plant was 79.5 tons of snapped raw product per hour, or 2777.8 cases of finished product per hour. This was predicated on a maximum of two 10-h shifts, leaving $4 \mathrm{~h}$ daily for equipment cleaning and repair. The average number of hours worked per day during the packing season was budgeted at something less than $20 \mathrm{~h}$ to allow for equipment breakdown and the occasional shortage of raw product, which in any agricultural operation based on a rapidly growing, highly perishable product would be expected to occur from time to time.

\section{The 28-30 Aug. harvest increment}

By Pack Day 22 (28 Aug.) in 1989 , the company had harvested 3128 acres $(36 \%)$ of the 8744 planted (Exhibit 2). However, the 21,863 tons of raw product processed represented $\approx 40 \%$ of the planned raw product volume, and the 706,506 cases produced represented $37 \%$ of the planned annual output. A bout two-thirds of the pack was at high-fancy grade, hence the slightly low figure ( $37 \%$ vs. $40 \%$ ) on recovery would not be unexpected.

A series of factory breakdowns had reduced average hourly output by $\approx 12 \%$, based on tons of raw product processed, and by $\approx 28 \%$ based on cases produced. By Day 22 the factory had

Exhibit 2. Annual production plan and daily cumulative production summary of sweet corn by St. Croix Valley Foods, Inc., 28 Aug. 1989 (Pack Day 22).

\begin{tabular}{|c|c|c|c|c|c|}
\hline \multicolumn{6}{|c|}{ Acreage } \\
\hline \multicolumn{2}{|c|}{ Planted } & 9,500 & --- & 8,744 & \\
\hline \multicolumn{2}{|c|}{ Harvested } & 9,238 & 98 & 3,128 & \\
\hline \multicolumn{2}{|c|}{ Purchased } & -- & 86 & 382 & \\
\hline \multicolumn{2}{|c|}{ Sold } & --- & 0 & 66 & \\
\hline \multicolumn{2}{|c|}{ Abandoned } & 262 & 0 & 0 & \\
\hline \multicolumn{2}{|c|}{ Balance } & & 184 & 5,550 & \\
\hline \multicolumn{6}{|c|}{ Data } \\
\hline \multicolumn{2}{|c|}{ Tons harvested } & 54,406 & 508 & 18,136 & \\
\hline \multicolumn{2}{|c|}{ Tons purchased } & --- & 470 & 4,083 & \\
\hline \multicolumn{2}{|c|}{ Tons sold } & --- & 0 & 290 & \\
\hline \multicolumn{2}{|c|}{ Tons processed } & 54,406 & 913 & 21,863 & \\
\hline \multicolumn{2}{|c|}{ Cases (303 equiv.) } & $1,900,000$ & 37,024 & 706,506 & \\
\hline \multicolumn{2}{|c|}{ Plant hours } & 684 & 15 & 353 & \\
\hline \multicolumn{6}{|c|}{ Yield } \\
\hline \multicolumn{2}{|c|}{ Tons } & 5.89 & 5.19 & \multicolumn{2}{|c|}{5.68} \\
\hline \multicolumn{2}{|c|}{ Cases processed/ton } & 34.92 & 40.51 & \multicolumn{2}{|c|}{32.32} \\
\hline \multicolumn{6}{|c|}{ Factory production } \\
\hline \multicolumn{3}{|c|}{ Tons processed/ } & 60.9 & \multicolumn{2}{|l|}{61.90} \\
\hline \multicolumn{2}{|c|}{ Cases/factory-hour } & 2777 & 2468 & 2000 & \\
\hline \multicolumn{6}{|c|}{ Cases packed by can size } \\
\hline \multicolumn{2}{|c|}{$24 / 303$} & $1,668,000$ & 23,358 & 546,128 & \\
\hline \multicolumn{2}{|c|}{$48 / 8$} & 48,000 & 0 & 40,426 & \\
\hline \multicolumn{2}{|c|}{$24 / 12$} & 184,000 & 13,666 & 119,952 & \\
\hline \multicolumn{2}{|c|}{ Total } & $1,900,000$ & 37,024 & 706,506 & \\
\hline \multicolumn{6}{|c|}{ Quality factor } \\
\hline$\% \mathrm{~A}$ & $20.0 \%$ & 380,000 & 0 & 447,084 & $63.3 \%$ \\
\hline$\% \mathrm{~B}$ & $71.3 \%$ & $1,354,700$ & 37,024 & 224,254 & $31.7 \%$ \\
\hline$\% \mathrm{C}$ & $8.7 \%$ & 165,300 & 0 & 35,166 & $5.0 \%$ \\
\hline$\% \mathrm{D}$ & $0.0 \%$ & 0 & 0 & & $0.0 \%$ \\
\hline$\% \mathrm{E}$ & $0.0 \%$ & 0 & 0 & & $0.0 \%$ \\
\hline Total & $100.0 \%$ & $1,900,000$ & 37,024 & 706,054 & $100.0 \%$ \\
\hline
\end{tabular}

averaged only 2000 cases per hour vs. the planned 2778.

Preharvest (pregrade) data on 25ear samples taken from 17 fields on 28 Aug. and from 18 on 30 Aug. with 12 growers (1276 acres) in common re flected the rapid change in corn maturity (Exhibit 3). On 28 Aug. the company judged that the corn on eight farms (626 acres) (Farms 3, 5, 6, 7, 9, 11,13 , and 15) was ready for harvest. With normal yields, the acreage would have been harvestable in about 2.5 days, depending on weather. However, by 30 Aug. the corn on 11 farms (1060 acres) was judged as ready, and corn on five farms (640 acres) had carried over from 28 Aug. (Exhibit 3). Clearly, a matter of some urgency had developed-factory output was less than- had been planned and also too many fields were approaching prime maturity simultaneously. There was need for a decision on harvest sequence and as to whether or not all fields would be harvested.

Normally, with an overbooked schedule the company might divert some of the tonnage to one of its other plant locations. However, at this time the other plants also were packing at full capacity and could not accept additional raw product.

Consideration of the alternatives had to be weighed carefully. If a crop satisfactory for processing was grown by a contract farmer, the company, by the terms of the contract, was obliged to pay the farmer for it whether or not it was harvested for processing (Exhibit 4). If it was not harvested, the farmer, therefore, would not only have the payment but the corn as well. The company was obliged only to pay for bypassed corn that was physically harvestable and was of satisfactory quality. Thus, uncontrolled weed, disease, and insect outbreaks that reduced crop acceptability would reduce payment, or might entirely relieve the company of payment responsibility. Similarly, if storm damage reduced harvestable yield, the company had to pay the farmer only for that proportion of satisfactory quality that could be obtained by the harvesting equipment.

The normal outlet for bypassed corn was as a fermented silage of somewhat lower quality than traditional silage from field corn. Bypassed fields of sweet corn would not dry down quickly for use as a shelled, storable grain. Slow drying and sus- 
Exhibit 3. Pregrade evaluation of sweet corn fields nearing harvest on 28 and 30 Aug. 1989, and supplementary notes pertaining to these fields.

\begin{tabular}{|c|c|c|c|c|c|c|c|c|c|}
\hline $\begin{array}{l}\text { Date } \\
\text { planted }\end{array}$ & Grower & Variety & Acres & $\begin{array}{c}\text { Estimated } \\
\text { yield }\end{array}$ & Moisture & & Prime & $\begin{array}{r}\text { Ear tall } \\
\text { Marginal } \\
\end{array}$ & Immature \\
\hline 26 May & 1 & Jubilee & 76 & $\approx 5.0$ & 73.64 & & 20 & 5 & 0 \\
\hline 25 May & 2 & Jubilee & 82 & $\approx 5.0$ & 73.36 & & 16 & 9 & 0 \\
\hline 27 May & 3 & Jubilee & 60 & $5+$ & 72.29 & & 22 & 3 & 0 \\
\hline 29 May & 4 & Jubilee & 114 & 5.0 & 74.40 & & 19 & 6 & 0 \\
\hline 29 May & 5 & Jubilee & 40 & 5.0 & 73.27 & & 24 & 1 & 0 \\
\hline 30 May & 6 & Jubilee & 72 & 5.5 & 73.61 & & 23 & 2 & 0 \\
\hline 31 May & 7 & Jubilee & 100 & 5.5 & 74.03 & & 24 & 1 & 0 \\
\hline 1 June & 8 & Jubilee & 90 & $4.5+$ & 73.69 & & 17 & 7 & 1 \\
\hline 1 June & 9 & Jubilee & 154 & 5.5 & 72.88 & & 22 & 3 & 0 \\
\hline 2 June & 10 & Jubilee & 196 & $5+$ & 74.56 & & 21 & 4 & 0 \\
\hline 2 June & 11 & Jubilee & 40 & $5+$ & 73.66 & & 22 & 3 & 0 \\
\hline 4 June & 12 & Jubilee & 58 & $5+$ & 73.32 & & 21 & 4 & 0 \\
\hline 4 June & 13 & Jubilee & 50 & 4.5 & 72.34 & & 23 & 2 & 0 \\
\hline 5 June & 14 & Jubilee & 140 & 6.0 & 76.47 & & 5 & 15 & 0 \\
\hline 2 June & 15 & $\begin{array}{c}\text { Crisp N' Sweet } \\
710\left(s h^{2}\right)\end{array}$ & 150 & 5.8 & 77.63 & & 24 & 1 & $\mathbf{0}$ \\
\hline 5 June & 16 & Jubilee & 54 & & 72.95 & - & $21-$ & 4 & $\mathbf{0}$ \\
\hline 2 June & 11 & Jubilee & 40 & & 72.20 & & $21-$ & $4+$ & 0 \\
\hline 29 May & 5 & Jubilee & 40 & & 71.93 & & 25 & 0 & 0 \\
\hline 26 May & 1 & Jubilee & 76 & & 70.63 & & 25 & 0 & $\mathbf{0}$ \\
\hline 30 May & 6 & Jubilee & 200 & & 72.24 & & 23 & 2 & 0 \\
\hline 1 June & 8 & Jubilee & 90 & & 70.91 & & 24 & 1 & $\mathbf{0}$ \\
\hline 1 June & 9 & Jubilee & 154 & & 69.26 & & 25 & 0 & $\mathbf{0}$ \\
\hline 29 May & 4 & Jubilee & 114 & & 72.06 & & $25-$ & 0 & $\mathbf{0}$ \\
\hline 4 June & 12 & Jubilee & 58 & & 71.24 & & $21-$ & 4 & $\mathbf{0}$ \\
\hline 4 June & 13 & Jubilee & 50 & & 70.58 & & 25 & 0 & 0 \\
\hline 5 June & 14 & Jubilee & 140 & & 72.00 & & $20-$ & 5 & $\mathbf{0}$ \\
\hline 6 June & 17 & Jubilee & 40 & & 70.81 & & $25-$ & $\mathbf{0}$ & $\mathbf{0}$ \\
\hline 6 June & 18 & Jubilee & 50 & & 71.52 & & $25-$ & 0 & $\mathbf{0}$ \\
\hline 25 May & 2 & Jubilee & 82 & & 70.16 & & 20 & 5 & 0 \\
\hline 5 June & 19 & Jubilee & 38 & & 73.61 & & $18-$ & 7 & 0 \\
\hline 2 June & 10 & Jubilee & 196 & & 70.77 & & 25 & 0 & 0 \\
\hline 6 June & 20 & Jubilee & 50 & & 71.81 & & 25 & 0 & 0 \\
\hline
\end{tabular}

ceptibility to stalk and ear rots precluded harvest for grain. If, on the other hand, the company decided to harvest an over-age field, it would have to have a market outlet for the canned product. If the crop was processed for canning, a major add-on expense would have been incurred. Furthermore, additional costs would be incurred in storing the processed product before marketing, and market penetration might be unsuccessful.

\section{The decision}

The fields in question at this time of the 1989 season were located in St. Croix and Chestnut counties of Minnesota (Exhibit 5). On 28 Aug. the harvest crews were located in the Preston, Minn., area near Farm 6, having harvested fields south of that community on 26 and 27 Aug. Blume had to decide which field to harvest next and develop a sequence that would be commensurate with highest product quality, minimal expense in harvesting and hauling, and protective of good liaison with the company's contract farmers. In addition to the pregrade data, he had some knowledge of the soils and the farming operation of each contract grower, as well as various notes about the fields (Exhibit 6). The soil in all fields was sufficiently dry to permit harvest.

Weather information in the contract area for 25-30 Aug. and the weather forecast for the next several days were available and were evaluated frequently by TV monitor (Exhibits 7 $A$ and B). Blume kept in close touch with the U.S. Weather Bureau, especially for the 24- to 48-h forecast. There was a $30 \%$ to $40 \%$ probability for rain on 28 and 29 Aug. in the contract area, with an increase to $60 \%$ by the evening of 31 Aug. Not only the possibility of heavy rain but also the temperature forecast was of concern to Blume. He knew that as the temperature increased, the sugar content of sweet corn decreased, and that the association between the two was approximately linear (Exhibit 8A). Higher temperatures also would increase the likelihood of off-flavor de velopment in the canned product following temporary storage on the receiving platform outside the factory (Exhibit 8B).

The weather had turned unsettled during the preceding few days. There had been some strong localized winds and sweet corn lodging in recent days, and some farmers were becoming nervous. Farmers 5, 14, and 19 in particular had been calling in at least once daily inquiring about timing of harvest. 


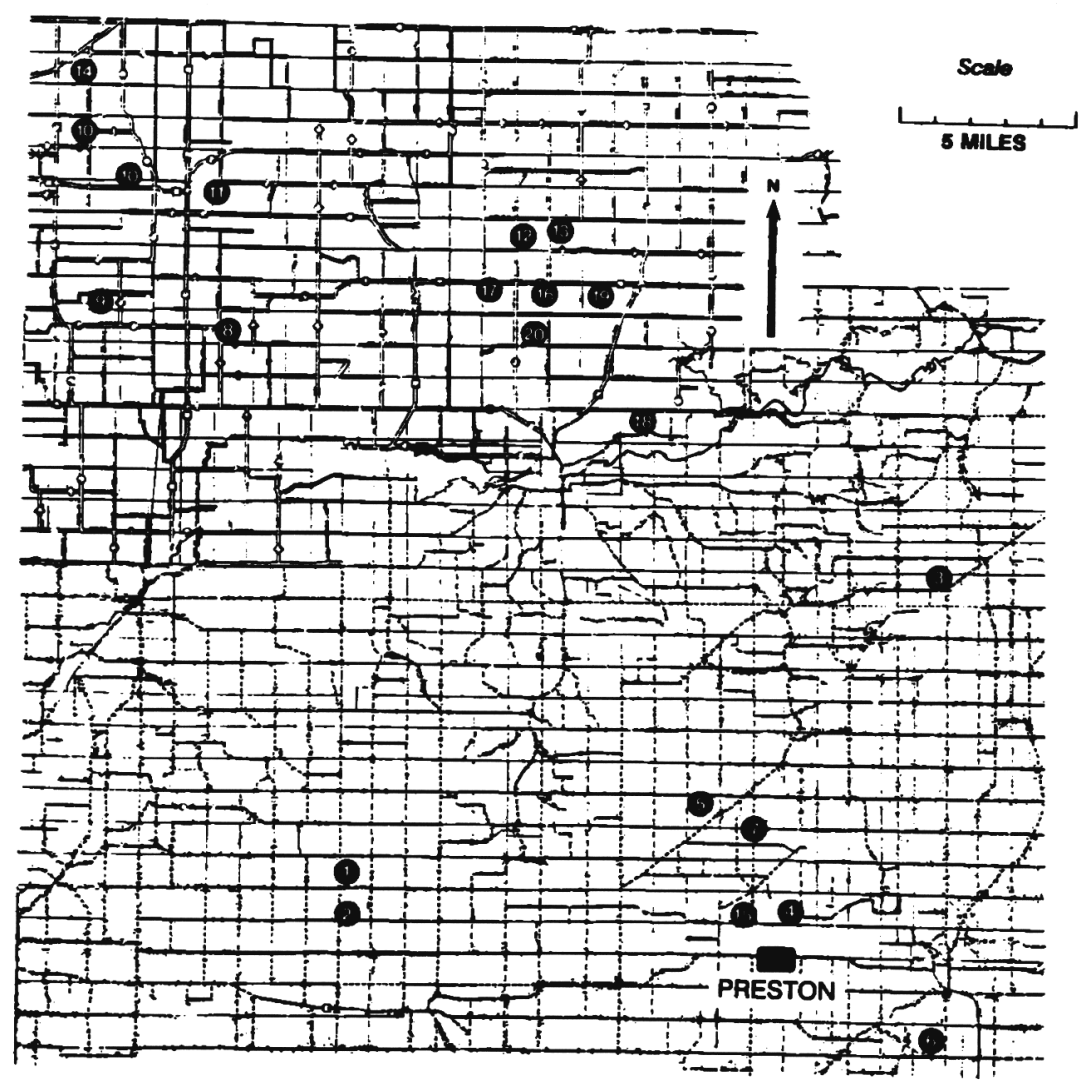

Exhibit 5. Map location of farms with sweet corn nearing prime harvest maturity on 2830 Aug. 1989.

\section{ABBREVIATED INTERPRETIVE NOTE}

The following commentary is intended to provide guidance to potential instructors. Alternative answers to sample questions and rationale for those answers have not been included but are available from D.W.D.

\section{Case objectives}

The main objective of this decision case is to providestudents with experience in problem analysis and decision-making typical of that faced by an agricultural manager of a firm that processes a highly perishable product from contract acreage. The situation chosen is representative of the upper Midwest but easily could be found virtually anywhere in the United States and with fairly diverse crops.

\section{Major issues in the case}

This case focuses on a critical area of responsibility for John Blume, the agricultural manager-decision-making regarding the sequence in which sweet corn fields nearing maturity will be harvested. While crop variety, preharvest sampling data, and planting date are major factors in determining the harvest sequence, many other factors may enter into the decision when several fields appear to be maturing at the same time. Such dilemmas are a realistic component in many areas of agriculture, particularly where the situation is changing rapidly and timely decisions must be made. This case draws on one's knowledge of the impact of soil type, weather, market strategy, local geography, equipment logistics, and the dynamics of crop status in each field.

The case involves three sectors of the production process-the contract farmer, raw product flow to the factory, and within-factory production. Although their goals are interrelated and each must assist the other in becoming successful, they each view the enterprise from a different perspective.

It must be remembered also that there are no outlets for an inferior product; neither is there a government support program to supply a price floor. Extra product may be unsalable regardless of quality.

The student must recognize that decision-making is mandatory, some- times on short notice, and that a decision once made will be implemented quickly and, therefore, probably cannot be reversed.

\section{Student background to use this case}

Students and industry trainees from a variety of backgrounds and from several college majors might seek employment as an agricultural manager as depicted in this case. Furthermore, those graduates who at some point in their post-college professional career will work above, below, or in parallel to the agricultural manager will benefit from exposure to the decisions in this case. The case was designed for use in an interdisciplinary senior-level "capstone" course in integrated management ofcropping systems, but could be used in other courses. Students are expected to have had prior coursework in horticulture or agronomy and soil science, although the type and extent of their knowledge will vary, depending on specific courses taken and practical work experience on the farm or in other phases of the agricultural industry. Students from other majors, such as agricultural education, natural resources and environmental studies, and food science, also might enroll in the course.

\section{Suggested teaching approach}

It is of great benefit to have students with diverse backgrounds interacting in the deliberations that arise in this case. Thus, teams of three to five students could provide the basis for this interaction. The case might be presented by the instructor as part of an initial class period. Three presentation options might be considered, depending on the degree ofexperience of the students with the case study method and the production and processing of highly perishable crop products. These three options are:

1) Present the case in considerable detail, providing questions that assist the students in analysis leading toward the major decision (recommendation).

2) Do not present the case. Instead, hand it to the students and request an oral or written report at a specified date. Provide guidance at a post-report discussion. 
3) Present the case by orally providing a brief framework of the situation. Provide time in subsequent meetings for questions and discussion of issues and, subsequently, re ceive written or oral reports of recommendations.

Option 3 might be preferred. Teams would be expected to report orally and enter into follow-up discussion with the instructor during the third class period, with part of the interim class period used for interaction with the instructor and other teams. Duringthese three class periods, the students also typically are doing work on a longer-term case; thus, there may be some overlapping of cases.

Each team deliberates the case outside of class following its assignment and prepares an oral presentation of its problem analysis and decision recommendations. A spokesperson for each team then presents the case analysis and decision rationale during the reporting period. All students from each team must participate in preparation of the defense and discussion. Different students within the team assume the role of spokesperson on subsequent and preceding cases.

\section{References}

The essential references associated with the case "Agricultural Manager's Dilemma" are provided as the "exhibits" in the text of the case.

Students also are permitted to obtain information from and discuss the case with faculty and other re-

Exhibit 6. Supplementary notes on contract farms and on fields nearing prime harvest maturity on 28-30 Aug. 1989.

\begin{tabular}{|c|c|c|c|}
\hline Contract & Scope of operation & Soils/site & Crop situation \\
\hline 16 & $\begin{array}{l}\text { Cash crop and swine, } \\
\text { cattle feeding }\end{array}$ & $\begin{array}{l}\text { Rolling clay loam } \\
\text { nonirrigated }\end{array}$ & Two fields \\
\hline 11 & Cash crop & $\begin{array}{l}\text { Loam, sand/gravel } \\
\text { subsoil, nonirrigated }\end{array}$ & $40 \%$ Lodged \\
\hline 5 & Cash crop & $\begin{array}{l}\text { Productive heavy soil } \\
\text { nonirrigated }\end{array}$ & $50 \%$ Lodged \\
\hline 1 & Dairy and cash crop & $\begin{array}{l}\text { Productive heavy soil } \\
\text { nonirrigated }\end{array}$ & $\begin{array}{l}\text { Uneven crop start } \\
\text { and some drought }\end{array}$ \\
\hline 6 & Dairy and cash crop & Rolling terrain & Eight fields \\
\hline 8 & Cash crop and swine & Sandy loam & Some drought \\
\hline 9 & $\begin{array}{l}\text { Cash crop and } \\
\text { cattle feeding }\end{array}$ & Black soil over sand & 80\% Lodged \\
\hline 4 & $\begin{array}{l}\text { Cash crop and dairy, } \\
\text { cattle feeding }\end{array}$ & Clay loam/rolling & Good yield \\
\hline 12 & $\begin{array}{l}\text { Cash crop, } \\
\text { off-farm employed }\end{array}$ & Lighter clay & $\begin{array}{l}80 \% \text { Lodged, } \\
\text { heavy yield }\end{array}$ \\
\hline 13 & $\begin{array}{l}\text { Cash crop, } \\
\text { off-farm employed }\end{array}$ & Sandy loam & Good yield \\
\hline 14 & Cash crop & Irrigated/flat terrain & $\begin{array}{l}80 \% \text { Lodged, } \\
\text { good yield }\end{array}$ \\
\hline 17 & $\begin{array}{l}\text { Cash crop, } \\
\text { egg production } \\
\text { cattle feeding }\end{array}$ & $\begin{array}{l}\text { Light sandy loam/ } \\
\text { flat terrain }\end{array}$ & Okay \\
\hline 18 & $\begin{array}{l}\text { Cash crop and } \\
\text { cattle feeding }\end{array}$ & Sandy clay & Okay \\
\hline 2 & Cash crop & & Uneven \\
\hline 19 & $\begin{array}{l}\text { Cash crop and swine, } \\
\text { cattle feeding }\end{array}$ & High land (clay) & Leaning \\
\hline 10 & Cattle and cash crop & Good clay loam & $\begin{array}{l}\text { Three fields: } \\
60,20, \\
18 \text { acres, } \\
30 \% \text { lodged }\end{array}$ \\
\hline 20 & Cash crop and dairy & Sandy loam, irrigated & $\begin{array}{l}30 \% \text { Lodged, } \\
\text { good yield }\end{array}$ \\
\hline
\end{tabular}

source persons during their deliberation of the case. However, the course instructors only provide elaboration and clarification of case issues and should not discuss specific "solutions" with the students before the in-class presentation and defense.

\section{Video}

A 12-min silent video of the sweet corn harvest, processing, and waste disposal operations at St. Croix Valley Foods also is available to assist in providing a general background.

\section{Sample study questions for raising issues enabling decision-making}

Although the primary decision. needed should be apparent from a reading of the case, the instructor might choose to provide some leading questions. Other questions might be raised for further discussion after students have concluded their report. The following may be helpful.

1) How can one decide which fields are less valuable to the company than the others?

2) What does the grade distribution in the season's sweet corn pack to date tell us that can be useful as we attempt to develop harvest strategy?

3) Which fields, if harvested, are more likely to result in a) lower factory recovery and thus higher processing costs and b) lower product quality?

4) Which fields, ifbypassed, are less costly to the company in terms of minimum payment to the contract farmer?

5) Which fields, ifbypassed, are less costly to the company in terms of other costs?

6) Which fields, if bypassed, may be less costly to the company in its long-term operation? How should "cost" be determined in this? Are there hidden "costs" involved with some decisions, such as poor public relations?

7) Which contract farmer might be least anxious if his/ her fields are not harvested? And which might be most upset? How much weight should be given to this consider- 
Exhibit 7A. Weather forecasts for area of harvest fields.

Following are the daily forecasts for 29-31 Aug. 1989 from the National Weather Service for zones 16 (Twin Cities seven-county area, which indudes Dakota County) and 19 (southeastern Minnesota, induding Goodhue County) and for other zones immediately west of 16 and 19 in Minnesota, as shown on attached zone map.

4:15 AM CDT, Monday, 28 Aug 1989,. Minnesota zones 11, 12, 14, and 16.

Today mostly doudy, with a $40 \%$ chance of thunderstorms. High in middle to upper 70 s. Tonight partly doudy, with a $30 \%$ chance of thunderstorms. Low in upper 50 s to lower 60 s.

10:45 AM CDT, Monday, 28 Aug. 1989, zones 18 and 19.

This afternoon...variable cloudiness with a 30\% chance ofthunderstorms. High from 76 to 81 . Wind south 10 to 15 mph. Tonight...partly doudy, a $30 \%$ chance of thunderstorms. Low in the lower to middle 60 s.

10:45 AM CDT, Monday, 28 Aug. 1989, zones 11, 12, 14, and 16.

This afternoon.. .partly doudy, a $30 \%$ chance of thunderstorms. High in the upper 70 s to middle 80 s. Wind southeast 10 to 15 mph. Tonight.. .partly doudy, a $40 \%$ chance of thunderstorms. Low in the upper 50 s to lower 60 s.

4:15 AM CDT, Monday, 28 Aug. 1989, zones 16, 18, and 19.

This evening.. .variable cloudiness with a $20 \%$ chance of thunderstorms. Wind southwest 5 to 15 mph. Late tonight.. .clearing, low in the upper 50 s to lower 60s. Wind west 5 to $15 \mathrm{mph}$. Tuesday.. .partly to mostly sunny. High in the upper 70 s to lower 80 s. Wind west 10 to $20 \mathrm{mph}$. Wednesday... increasing doudiness with a 30\% chance of thunderstorms.

9:15 AM CDT, Monday, 28 Aug. 1989, zones 16, 18, and 19.

Tonight....partjy doudy, low in the upper 50s to lower 60s. Wind west 5 to $15 \mathrm{mph}$. Tuesday...partly to mostly sunny. High in the upper 70 s to lower 80s. Wind west 10 to $20 \mathrm{mph}$. Tuesday night.. .fair. Low in the upper 50 s to lower 60 s. Wednesday... increasing cloudiness with a $30 \%$ chance of thunderstorms. High in the upper 70 s to lower 80 s.

4:15 AM CDT, Tuesday, 29 A ug. 1989, zones 16, 18, and 19.

Today.. .partly to mostly sunny. High in the upper 70 s to lower 80s. Wind northwest to $20 \mathrm{mph}$. Tonight.. .fair. Low in the upper 50 s to lower 60 s. Wind light and variable.

10:45 AM CDT, Tuesday, 29 Aug. 1989, zones 16, 18, and 19.

This afternoon...mostly sunny. High in the upper 70s to lower 80s. Wind northwest 10 to 20 mph. Tonight...fair. Low in the upper 50 s to lower 60s. Wednesday.. increasing doudiness.

4:15 Am CDT, Tuesday, 29 Aug. 1989, zones 15, 16, 18, and 19.

Tonight...fair. Low in the lower to middle 50s. Northwest wind $10 \mathrm{mph}$ diminishing to light and variable toward morning. Wednesday.. .mostly sunny in the morning becoming partly doudy in the afternoon. High in the upper 70 s. Southeast wind 10 to 15 mph. Wednesday night and Thursday...30\% chance of showers and thunderstorms.

9:15 PM CDT, Tuesday, 29 Aug. 1989, zones 15, 16, 18, and 19.

Tonight...clear to partly cloudy with an isolated shower possible. Low in the lower to middle 50 s. Wind northwest 5 to 15 mph becoming light and variable. Wednesday...mostly sunny in the morning becoming partly cloudy in the afternoon. High in the upper 70s. Southwest wind 10 to $15 \mathrm{mph}$. Wednesday night and Thursday.. .30\% chance of showers and thunderstorms. Low Wednesday night in the lower 60s. High Thursday in the lower 80s. Wednesday.. increasing doudiness with a $30 \%$ chance of thunderstorms.

10:45 AM CDT, Wednesday, 30 Aug. 1989, zones 14, 15, 16, 18, and 19.

This afternoon...variable cloudiness with widely scattered showers and thunderstorms. High in the 70 s. Wind southeast 10 mph. Tonight...40\% chance of thunderstorms. Not so cool with a low in the lower 60 s. Wind southeast 10 to 15 mph. Thursday... . breezy with a $40 \%$ chance of thunderstorms. High in the lower 80 s.

4:15 PM CDT, Wednesday, 30 A ug. 1989, zones 15, 16, 18, and 19.

Tonight...partly cloudy with a $50 \%$ chance of thunderstorms after midnight. Low in the lower 60 s. Wind southeast 10 to $15 \mathrm{mph}$. Thursday...breezy with a $40 \%$ chance of thunderstorms. High in the lower 80 s. Wind south to southeast 15 to 25 mph. Thursday night...cloudy with a chance of showers and thunderstorms. Low in the middle 60s. Friday...mostly cloudy, a slight chance of showers. High in the upper 70 s.

9:15 PM CDT, Wednesday, 30 Aug. 1989, zones 16 and 19.

Tonight...partly cloudy with a $40 \%$ chance of thunderstorms after midnight. Low around 60 . Wind southeast 10 to 15 mph. Thursday...partly sunny and breezy with a $40 \%$ chance of thunderstorms. High in the lower 80 s. Wind south to southeast 15 to 25 mph. Thursday night....cloudy with a $60 \%$ chance of showers and thunderstorms. Low in the middle 60 s. Friday...mostly cloudy with a slight chance of showers. High in the upper 70 s. 


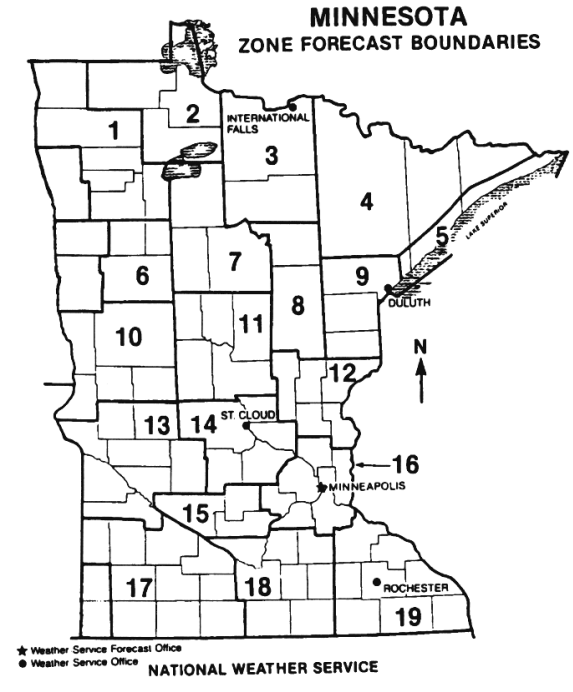

Exhibit 7B. Weather forecast zones for Minnesota. (adapted from U.S. Weather Service Forecast Map 87-5, issued 4 Aug. 1987)

ation in making the decision? How might contract farmers or others respond to a "no harvest" decision?

8) Why might the company accept some fields of older corn?

9) What is the most logical route for the harvest crews to follow to economize on road time and thus reduce "down time"?

10) Based on all considerations, which fields would you recommend be bypassed, if any, and why?

11) Why might the company

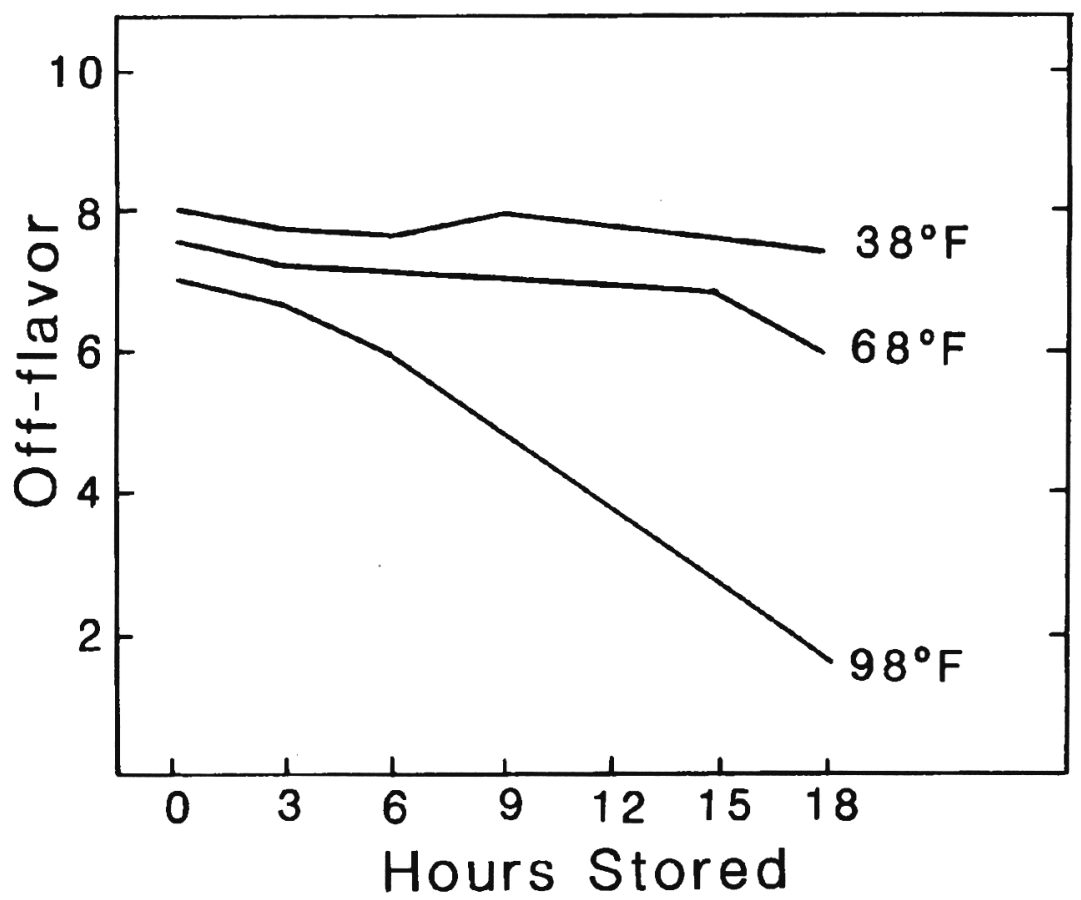

Exhibit 8B. The effect of storage time and storage temperature before processing on off-flavor of frozen whole-kernel sweet corn. "...flavor deteriorated and off-flavors developed faster than changes in sweetness. 0 ff-flavors did not develop when sweet corn was held 18 hours or less at 38F before processing and developed very slowly when held at 68F. Sweet corn held for 6 hours at 98F developed off-flavors typical of anaerobic respiration, although oxygen levels outside the husks were aerobic." Adopted from Smittle and Dean (1972). elect to harvest only part of a farmer's contract acreage rather than bypass it completely?

12) Describe the probable impact of weather conditions at the time on the decisionmaking process and on the resolution of the harvest-se quencing problem.

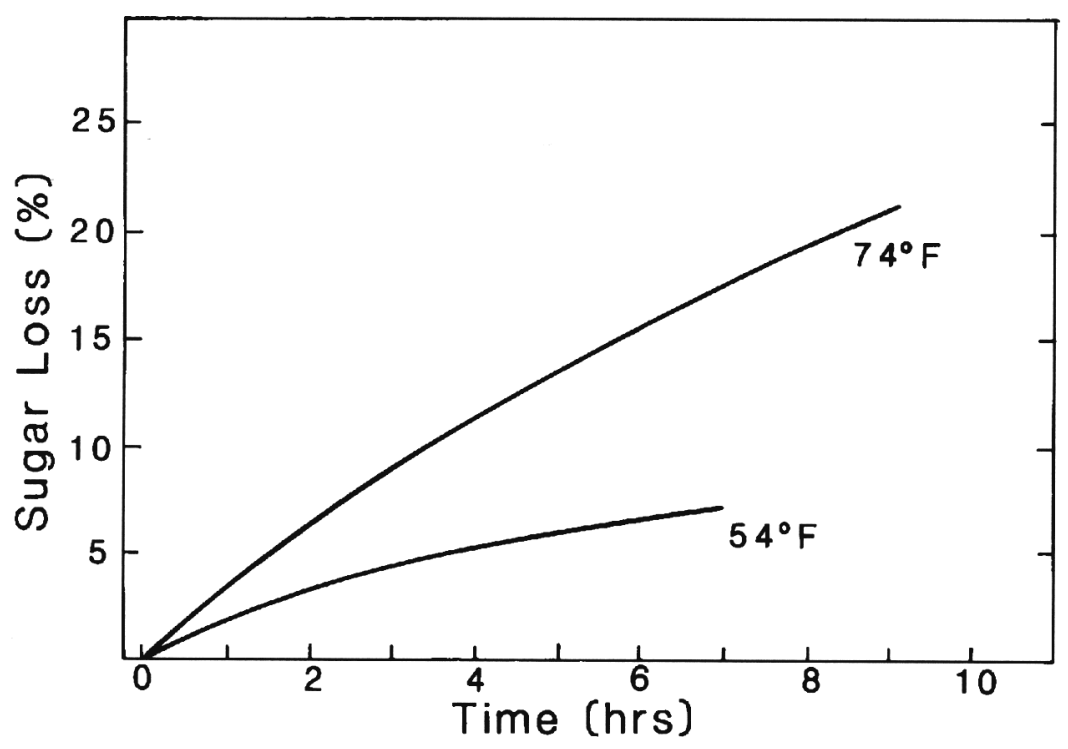

Exhibit 8 A. Effect of temperature and holding time on sugar loss of sweet corn. These data show that the rate of sugar loss more than doubles for each $18 \mathrm{~F}$ increase in temperature during the short periods between harvest and processing." Adopted from Smittle and Dean (1972).
13) N ow that you have acquired some familiarity with the decision-making process for budgeting, planting, and harvesting in the vegetableprocessing industry, are there alternative methods that you would suggest that might be an improvement over the current process?

\section{Literature Cited}

Smittle, D.A. and B.B. Dean. 1972. Sweet corn quality deterioration: A survey of industry practices and possible methods of control. Washington Agr. Expt. Sta. Circ. 555.

\section{Acknow ledgements}

Special appreciation is expressed to Melvin Stanford, visiting professor, College of Agriculture, Univ. of Minnesota, in the preparation of this decision case. The assistance of industry personnel in providing data and commentary for an authentic case study is gratefully acknowledged. Personnel and proprietary names, however, are not authentic, having been changed upon request. Copies of this case may be obtained from D.W.D. Copyright 1989. All rights reserved. 